gi seg whatsoever? Hem hevder at det over tid er umulig å stå i ubehaget og at vi ender opp med å tilpasse oss uansett. Er dette en programerklæring om avmakt? Fra vårt eget tidsskrift, på lederplass? Eller er det et subtilt budskap om det motsatte, som jeg ikke har fått med meg? Er det kanskje erting, for å få for eksempel meg til å trå over terskelen for første gang og stikke hodet frem, for eksempel i dette forum?

OK, da fungerer det etter hensikten. Hør her: Sammen er vi klinikere mye sterkere enn all slags administrasjonsfjas. Bortsett fra dem som søker hjelp, er det vi, hjelperne, som har legitimiteten i et hjelpesystem. Vi må stå i dette ubehaget $\mathrm{i}$ lang, lang tid og vise at vi tar byråkratmakta på utholdenhet. I kjærlighet til faget vårt - av og til er det tålmodigheten som varer lengst. Lenge leve ubehaget! Det er virkeligheten som må tilpasse seg. Ikke vi. No way. Her i Trondheim finnes det ett ultimat hvilested: Tilfredshet kirkegård.

\section{Harald Sundby}

har-su2@online.no

Harald Sundby (f. 1962) er spesialist i allmennmedisin og fastlege ved Kalvskinnet legesenter i Trondheim.

Ingen oppgitte interessekonflikter.

Litteratur

1. Hem E. Vi blir tilfreds til slutt. Tidsskr Nor Legeforen 2013; 133: 5

Publisert som rask respons i nettutgaven 11.1. 2013

\section{Hovedpersonen - hvem er det?}

Redaktørens oppskrift i Tidsskriftet nr. 1/2013 på hvordan vi skal redusere den kognitive dissonansen er i høyeste grad aktuell (1). Han beskriver tilpasningsmekanismer som faktisk fungerer - og som våre ledere krever at vi aksepterer. Systemlojaliteten går foran pasientlojaliteten i Det Nye Norske Helsevesen. Jeg vil gjerne sitere en tidligere sjef: «Det viktigste er ikke hva som er best for pasienten, men hva som er best for systemet.» Systemet belønnet sjefen med ytterligere avansement. I så henseende har redaktøren rett - de tilpasningsdyktige finner seg til rette overalt. Men det er kun tidsbegrenset.

Helsevesenet er inne i en periode med nye regler, nye normer og nye maktstrukturer. For fagpersonene er det underlig å se at ledere uten aktuell fagkompetanse får legalisert sin «rett» til å overprøve medisinske beslutninger. I et av sykehusene ved Oslofjorden er det en sykepleierleder som godkjenner kirurgiske fagprosedyrer. Legenes fagmakt svekkes ved at formell hierarkisk makt styrkes (2) - godt hjulpet av juridifiseringen av helsevesenet. Redaktøren beskriver kognitiv dissonans mellom fagperson og administrative enheter. Siden fagpersonene ikke har formell makt, er overlevelsesstrategien å tilpasse seg.

Kjære kollegaer, kjære redaktør - det er én part som er utelatt fra betraktningene. Det er hovedpersonen - pasienten. Pasientene har også makt. De har sin individualiserte makt definert i pasientrettighetsloven. Men de har også forbrukermakt og kunnskapsmakt. Informasjonsteknologien har for lengst revolusjonert forholdet mellom lege og pasient. Det er illusorisk å tro at dagens unge vil akseptere et helsevesen som prioriterer systemlojalitet fremfor hensynet til den pasienten vi har rett foran oss. Når pasientene våkner, bokstavelig talt, vil den kognitive dissonansen bli enorm dersom vi velger å satse på dagens rådende styringsideologi. Og hvis Hippokrates ser oss nå, vil han sikkert lure på hvorfor $\mathrm{i}$ all verden vi har laget et helsevesen som ikke har individet i sentrum.
Elisabeth Hegstad (f. 1956) er spesialist i gastrokirurgi, dr.med. og master i helseadministrasjon.

Ingen oppgitte interessekonflikter.

\section{Litteratur}

1. Hem E. Vi blir tilfreds til slutt. Tidsskr Nor Legeforen 2013; 133: 5 .

2. Slagstad R. Helsefeltets strateger. Tidsskr Nor Legeforen 2012; 132: 1479-85.

Publisert som rask respons i nettutgaven 11.1. 2013

\section{De og vi}

Redaktørens intrigante leder i Tidsskriftet nr. 1/2013 er bygd opp rundt diskutable forutsetninger og en sammenblanding av «de» og «vi» (1).

Det er ingen grunn til å anta at dagens organisering er kostnadseffektiv. Etter at vi i alle år er blitt innprentet at det har vært en uregjerlig kostnadsvekst, befinner stadig våre helsekostnader seg midt i OECD-klassen. Det nye er at det har vært en kraftig reduksjon i sengetall og antall liggedøgn - uten samtidig kostnadsreduksjon. Til tross for aktivitetsvekst vokser køene.

Hvem og hva er det vi behandler? Ressursene dreies mot et voksende styrende lag av kvalitetsdirektører, kommunikasjonsarbeidere, byråkrater og konsulenter, i foretak, regionforetak og departement. Og den egentlige virksomheten utarmes. Dissonansen oppstår mellom det $d e$ tenker og det vi gjør, ikke mellom det $v i$ tenker og det vi gjør. Dette er vesensforskjellig. All den tid meningen oppstår i møtet mellom helsearbeideren og pasienten, vil ikke handlingen først og sist styres som de tenker. Den internaliserte konflikten hos helsearbeideren overvurderes, bruddet oppstår mellom de styrende og de som styres.

Ubalansen mellom egenvekt og egenmakt hos dem som forestår den egentlige virksomheten, destabiliserer den rådende organiseringen, som det er skjedd med utallige andre politiske og organisatoriske systemer opp gjennom historien. Det er dette fenomenet som er naturgitt. De $100 \%$ tilpasningsdyktige tilpasses ellers alle organisasjoner og politiske systemer - uten at dette gjør verden til et uforanderlig sted.

Magnussen etterspør eksempler på gunstige «ineffektive» legepasient-forhold. Svaret avhenger av hvilket effektmål som legges til grunn. I dagens system er det utallige eksempler på «ineffektive» lege-pasient-forhold. Å la pasienten ligge et ekstra døgn. Å ringe pårørende. Å overtale pasienten til ikke å la seg operere unødig. $\AA$ gi god informasjon. $\AA$ ta seg den tiden det tar.

\section{Christian Grimsgaard}

cgrimsga@ous-hf.no

Christian Grimsgaard (f. 1969) er overlege ved Avdeling for hånd- og mikrokirurgi, Klinikk for kirurgi og nevrofag, Oslo universitetssykehus, Rikshospitalet.

Ingen oppgitte interessekonflikter.

\section{Litteratur}

1. Hem E. Vi blir tilfreds til slutt. Tidsskr Nor Legeforen 2013; 133: 5 .

Publisert som rask respons i nettutgaven 12.1. 2013 